\title{
De dansksindede soldater og Verdenskrigen 1914-18
}

\author{
af Michael Klos
}

Hvordan reagerede de dansksindede soldater i 1. Verdenskrig på krigens »tunge byrde «? Den officielle holdning var, at de skulle påtage sig krigstjenesten for derved at bevare retten til deres danske hjemstavn. Men man kunne unddrage sig krigstjenesten - ved krigsfangenskab eller desertering. Michael Klos har fundet eksempler, som giver glimt af de dansksindedes holdning til krigen, og som antyder, hvad der lå bag de mange deserteringer. De viser også, hvordan det tyske militær søgte at hindre, at de dansksindede unddrog sig krigens byrde.

\section{En altomfattende krig}

Studiet af den 1. verdenskrig er grundlæggende for forståelsen af udviklingen i Europa i det følgende århundrede. Krigen var med til at udvikle den nye samfundstype: massesamfundet. Konfrontationerne blev totale, det vil sige, at hjemmefronten blev inddraget $i$ et indtil da ukendt omfang. Man kunne ikke længere skille krigsfronten fra hjemmefronten. I det tyske rige blev der f.eks. d. 5. dec. 1916 vedtaget en lov om 'Vaterländischer Hilfsdienst'. Ifølge denne lov skulle alle mænd fra 17 til 60 år yde en arbejds- eller militærtjeneste. ${ }^{1}$

Krigshandlinger blev ikke længere domineret af kampen mand mod mand, hvor den enkelte stod ansigt til ansigt med fjenden. Døden kom i form af daglangt varende bombardementer, effektive maskingeværer, gasangreb, tanks, flyvemaskiner og andet nyt fra arsenalerne. ${ }^{2}$ I begyndelsen af krigen kunne den tyske ledelse bruge sine mandlige borgere som soldater, uden at skænke det særlige tanker. Den militære ledelse regnede med, at den geniale angrebsplan (Schlieffenplan) ville afslutte krigen $\mathrm{i}$ løbet af kort tid. Man talte om en sommerudflugt til Paris. Men udviklingen blev en anden. Den tyske ledelse kom hurtigt ud for det problem, at man på én og samme tid manglede mandlige, faglærte arbejdere og soldater. Industrien påpegede klart, at uden et kvalitativt og kvantitativt arbejdspotentiel ville krigsproduktionen bryde sammen. Man sendte da i stigende grad unge til fronten. De aldre og især faglærte blev i stedet reserveret til tjeneste $i$ industrien som săkaldte »reklamerede«. På trods af militærets personalebehov talte man i marts 1918 ca. 3 millioner ikke indkaldte militæranvendelige personer, og af dem var omkring $50 \%$ krigs-anvendelige. $^{3}$ 
Ser man på statistikken over de faldne tyske soldater, så træder en rystende lidelseshistorie frem. Den aldersgruppe, der led de største tab, var de 20-25 år gamle. De tegnede sig for næsten $40 \%$ af alle døde. Tager man de yngre med, det vil sige de 15-19 årige, så var der tale om hele 49\%. Aldersgruppen 19-20 år startede i 1914 med de laveste tabstal (i gruppen 19-25 år), for i 1918 at overgå alle andre (se fig. 1). Det er denne gruppe, der som den eneste har en kontinuerligt stigende tabsstatistik. Læser man E. M. Remarque: 'Intet nyt fra Vestfronten', får man et klart billede af de unge rekrutter, der i slutningen af krigen kom til fronten som ren kanonføde: »Vore friske Tropper er blodfattige, svagelige Drenge, som ikke kan bære et Tornyster, men som forstaar at dø. I Tusindvis. De kender ikke noget til Krig, de rykker kun frem og lader sig skyde ned. $\aleph^{4}$ En for kort og utilstrækkelig uddannelse og manglende erfaring i skyttegravskrig med mere gjorde det vanskeligt for dem at overleve.

Figur: $1^{5}$

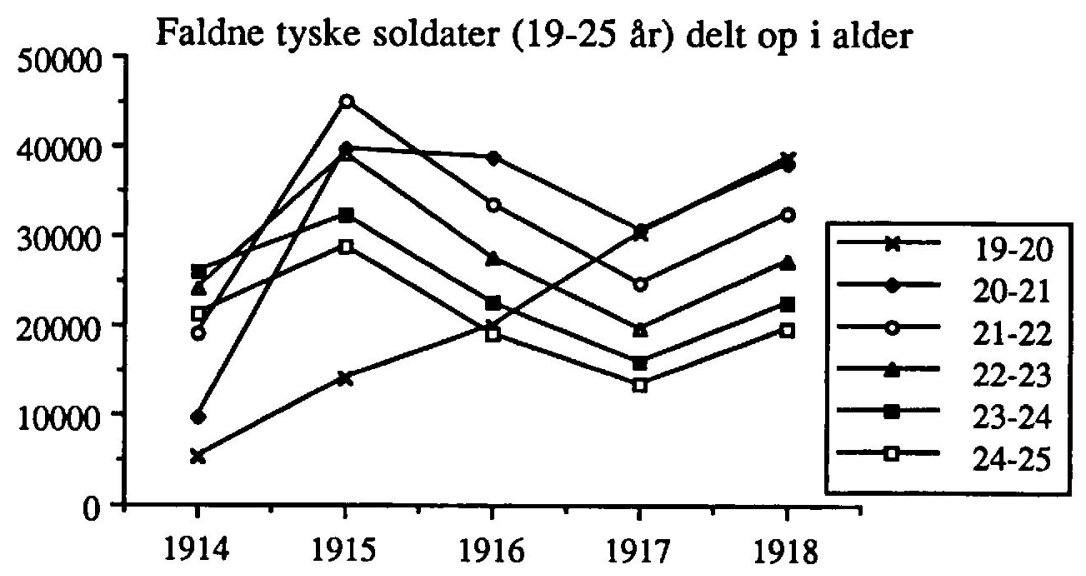

\section{Den første krigsbegejstring}

De ovennævnte tabstal var i august 1914 en utænkelighed og manglede i generalstabens kalkuler. Man regnede med at kunne slå fjenden, ligesom man havde gjort i den sidste krig mod Frankrig i 1870-71.

De eksisterende modsætninger i samfundet blev lagt på hylden. Borgfreden blev en kendsgerning. Optimister håbede, at man nu var gået fra »klassesamfund " (Gesellschaft) til et "folkefællesskab « (Gemeinschaft). ${ }^{6}$ Kejser Wilhelm d. II's så berømte ord den 4. august 1914:7 »Ich kenne keine Parteien mehr, Ich kenne nur Deutsche!«, viste sig ligesom fællesskabstanken at være en 
illusion. Den 4. august 1914 druknede modsætningerne i samfundet i den nationale 'eufori'.

Den flensborgske overborgmester Dr. Todsen holdt ti dage senere en tale, hvor han meget patetisk bl.a. sagde følgende: "Den store krig, som det tyske rige på trods af sin kærlighed til freden er blevet presset ind i af sine modstandere i øst og vest, kræver uhyre anstrengelser af vort folk. Men gud være lovet, det tyske folk er i stand til at bare byrden. Vi har set alle våbenførende mænd i fællesskab ile til fanerne. Det skete ikke med let sind, men dog glad og beredt til at ofre livet for fædrelandet. ${ }^{8}$

Denne tale er ikke enestående for den såkaldte auguststemning i Europa. Lignende taler holdtes overalt $\mathrm{i}$ de krigsførende lande.

Den menige soldat var heller ikke upåvirkelig. Flensborgeren J. Ankersen var 20 år, da han $\mathrm{i} 1914 \mathrm{drog}$ af sted til fronten. I 1919 skrev han sine erindringer. Han beretter om afskeden med hjemmet og de forste indtryk med følgende ord: "Endnu en sidste afsked med far og søster før toget kørte af sted med 650 unge mennesker mod uvisheden og døden. Men det tænkte vi ikke på. Jublende og sejrssikre kørte vi gennem den i al sin herlighed stående hjemstavn, som vi ville forsvare mod de frække fjender. Og så modtagelserne på banegårdene. Overalt var der vajende faner, blomster, piger og kvinder fra det 'røde kors', som ville gøre alt muligt godt for os. Jeg kunne godt tænke mig at vide, hvor uendelig mange kopper kaffe og smørrebrød jeg tog til mig på denne rejse gennem Tyskland. Der var helt afgjort ikke tale om sult eller tørst, men opfattelsen af, at dette hørte med til sagen, og at man ikke skulle gå glip af oplevelsen." ${ }^{9}$

Men hvad var det egentlig man skulle til? Den moderne krigsførelse var et nærmest ukendt fænomen. Stillingskrigen, der første gang blev synlig i den russisk-japanske krig (1904-06), ansås som et produkt af en konflikt, hvor barbarer stod over for hinanden. Den kunne selvfølgelig ikke overføres på europxiske forhold - mente man. ${ }^{10}$ Virkeligheden blev en anden! Man oplevede en krig, der overgik selv de værste forestillinger.

Efter de første dage ved fronten skrev J. Ankersen: "Den brændende begejstring var blæst bort. Vi længtes ikke længere efter blodige, friske og glade kampe, kun hjem, hjem til vore kære. Hjem til forhold, hvor man atter kunne leve som menneske blandt mennesker, det var vores tanke. Ja, dengang var jeg allerede træt af krigen, mere træt end jeg nogen sinde blev det efter denne tid. Hvordan kunne det være? Måske fordi nerverne, der var spændt til det yderste, ikke kunne vænne sig til skyttegravskrigens ensformighed. ${ }^{11}$

Mange krigsfrivillige blev til krigsneurotikere - åndeligt knækkede, fordi de måtte gennem oplevelser, som lå langt fra deres erfaringshorisont.

Myten om den korte krig og den planlagte sommerudflugt til Paris endte 
brat. Füsilier-Regiment Königin nr. 86, og med det mange dansksindede, havde sit hovedkvarter i Flensborg. Regimentet drog i august 1914 med 70 officerer og 3025 menige til fronten. I alt mistede regimentet $\mathrm{i}$ løbet af krigens fire år 97 officerer og 3899 menige! ${ }^{12}$ Tabstallene overstiger altså den samlede styrke ved afrejsen i 1914.

\section{De dansksindedes reaktioner over for krigen}

Det er almindeligt kendt, at mange dansksindede deltog på tysk side i verdenskrigen. Fra hele Sønderjylland var det sandsynligvis mellem 22.500 og 30.000. De samlede tabstal lå på 16.538, af dem var mellem 4500 og 5000 dansksindede. ${ }^{13}$ Hvordan havde de dansksindede det med at drage $\mathrm{i}$ krig for det tyske rige? Bøjede de sig næsten loyalt under krigstjenestens nødvendighed, eller protesterede de, og i så fald: hvordan?

På det politiske plan blev kursen lagt af den danske rigsdagsmand H. P. Hanssen, som af taktiske grunde bl.a. stemte for krigsbevillingerne i den tyske rigsdag. På det mere daglige plan var de dansksindede fordelt på forskellige regimenter fra Slesvig-Holsten. De var med, og de høstede anerkendelse ... og døde. Vilhelm la Cour skrev i 1916: »Det ville være umuligt at angive, hvor de slesvigske Soldater i særlig Grad gik Døden under Øjne. De mødte den overalt $-\mathrm{i}$ Vest som i Øst eller nede i Makedonien. ${ }^{14}$

Marcus Lauesen skrev i 1939 om krigsudbruddet følgende: »Hvordan Krigens Udfald end vilde blive, - for Sønderjyderne vilde meget afhænge af den Stilling, de indtog overfor Mobiliseringsordren. En Udvigen maatte betyde Øgelse af Trykket og uanede Farer for Folkelivet ind i Fremtiden. Men baade tyske Myndigheder og civile Tilskuere maatte erkende, at der intet var at klage over; alle Sønderjyder i Alderen fra 20 til 45 Aar efterkom Mobiliseringsordren ... Det var ikke Lyst og Begejstring, der drev dem til Fanerne, men Bevidstheden om, at kun ved at opfylde deres tunge Pligter som tyske Statsborgere kunde de bevare Retten til at dyrke den hjemlige Jord, naar engang Krigen var forbi. ${ }^{15}$

En lignende vurdering af de dansksindedes holdninger under krigen findes i en samtidig politirapport, som er fremdraget af Hans Schultz Hansen i 1990: "Myndighedernes helt ubegrundede mistro til de dansksindede flensborgere resulterede $i$ en øget politiovervågning. I en rapport fra politiforvaltningen til overborgmesteren fra februar 1915 kunne det imidlertid kun konstateres, at de indkaldte danske soldater alle havde stillet sig under fanerne. Desertationer var ikke politiet bekendt. ${ }^{16}$

De sønderjyske krigsdeltagere opfyldte generelt deres tunge pligt. En af dem 
sammenfattede livet ved fronten på følgende måde: "Livet i skyttegraven var i mange måder ejendommeligt. På den ene side et paradis, eller slaraffenland. Intet at sørge for, intet at bryde sig om ... Men på den anden side var livet $i$ skyttegravene et helvede, et liv og leven på kanten af sin egen grav. Altid fardig og parat til at vandre herfra, til at blive mere eller mindre gjort til krøbling, til at løbe fra alt man havde, og enten ligge hjælpeløs, eller blive taget til fange. Hvert øjeblik nat og dag var man udsat for at ende sit liv på den mest ulykkelige måde. « ${ }^{17}$ Kombinationen mellem 'himmel og helvede' og det særlige fællesskab, som mændene udviklede i skyttegravene, udøvede en fascination. Ernst Jünger skrev i 1920 sine krigserindringer: "In Stahlgewittern«. Hans skildringer af krigen er detaljerede og nærmest rå. Han var meget optaget af krigen og opsøgte den nærmest. E. Jünger blev såret 14 gange, sluttede krigen med 20 krigsar og blev igen og igen dekoreret for sit mod (eller galskab!). I 1918 modtog han Tysklands fornemmeste militære orden 'Pour le mérité' for udvist mod. Hos E. M. Remarque kan man læse om en samtale blandt soldaterne. Udgangspunktet er spørgsmålet, hvad gør du når krigen er slut? En af dem svarer, at han vil være soldat! Det forstår de fleste ikke, men hovedpersonen reflekterer: "Man kan læse paa hans Træk, hvad han tænker. Derhjemme er der en ussel Rønne ude i Mosen, derhjemme er der det tunge Arbejde ude paa Heden fra tidlig Morgen til sen Aften i en stegende Varme, derhjemme er der den kummerlige Løn og det beskidte Arbejdstøj ... « $^{18}$

Samtidig med at de fleste dansksindede bøjede sig under nødvendigheden, har en del dog måttet spørge sig selv, hvad var meningen med krigen? Hvordan skulle man forholde sig til den? Man var fanget i de faste rammer, militæret satte. Der var principielt to muligheder at unddrage sig krigen på, hvis man ikke valgte døden eller f.eks. skød sig selv i benet. Man kunne vælge mellem fangenskab eller faneflugt. Begge muligheder var forbundet med store farer. Men var disse farer større end dem fra skyttegraven ${ }^{19}$

\section{Fangenskab}

Den tyske ledelse holdt øje med sine undersåtter. Problemet om hvorvidt det måske kunne være fristende for dansksindede soldater at falde $\mathrm{i}$ allieret krigsfangenskab blev berørt af »Apenrader Tageblatt « den 25. august 1914: ${ }^{20}$ "Den danske journalist Franz von Jessen har sendt følgende telegrafiske meddelelse til 'Kolding Folkeblad': Jeg har tidligere telegraferet, at de franske og russiske militærforvaltninger er blevet enige om, at tyske krigsfanger af polsk og elsass-lothrinsk afstamning skal nyde en fortrinsbehandling i Rusland og Frankrig. Jeg har derpå med det samme gjort de militære og civile myndigheder opmærksom på den kendsgerning, at der på tysk side står omkring 10.000 soldater med dansk nationalitet, som stammer fra Nordslesvig. Deres situation 
svarer fuldstandig til den, som folk fra Elsass-Lothringen og Polen er i. Jeg kan med største tilfredsstillelse meddele, at der er grund til at tro, at de førte forhandlinger mellem Paris og Petersborg har ført til, at soldater af dansk nationalitet, der kommer $\mathrm{i}$ fransk eller russisk fangenskab, vil nyde de samme fordele som folk fra Elsass og Polen.«

Den danske regering udtrykte officielt, at man beklagede dette privatinitiativ. Man kunne heller ikke andet, hvis man ønskede et godt forhold til naboen i syd. I det øjeblik, hvor de dansksindede krigsdeltagere blev klar over, at de $\mathrm{i}$ tilfælde af fangenskab ville få en bedre behandling, måtte man fra tysk side naturligvis frygte en nedgang i kampmoralen. Især når forholdene i den tyske hær i løbet af krigen blev stadig ringere fra år til år.

Allerede i 1915-16 kan man spore noget, der tyder på, at ovennæunte pressemeddelelse stemmer overens med den franske holdning over for de dansksindede. Under kampene ved vestfronten (Moulin og Quennevieres) den 16. juni 1915 tog franskmændene flere fanger. Blandt de tilfangetagne var efter sigende også dansksindede. I begyndelsen af 1916 fik det IX. armekorps' generalkommando en hemmelig meddelelse fra Frankrig. En udskiftningsfange havde kort før sin afrejse fået en seddel fra den tyske sergent Lorinsen, som temmelig kluntet skrev: "De folk ... som den 16. juni (1915 M.K.) blev taget til fange udgiver sig som danskere. Nogle franskmænd taler dansk med disse folk. De folk (tyskere) smed deres kokarder væk og skældte ud på Tyskland, de forbandede tyskere har jo ikke noget tilovers for os. - De franske officerer viser os kort, hvor der er nøjagtige opgivelser af skyttegrave, beskyttelsesrum, kanonstillinger og kommandocentraler. De dansktalende folk bliver altid afhørt og behandlet broderligt. $\aleph^{21}$ Anklagerne kan sammenfattes til noget $\mathrm{i}$ retning af landsforræderi!

Den 7. februar 1916 skrev krigsministeriet til politiforvaltningen i Flensborg om dansksindede soldaters aktiviteter $\mathrm{i}$ franske fangelejre. Krigsministeriet havde som kilde en tysk fange $\mathrm{i}$ fangelejren 'Blaye ved Bordeaux'. Kilden betegnes som troværdig og til at stole på. Den nævner en reservist F. Brandt, som er de dansksindedes tillidsmand og den omtaler »... (danskerne), som $\mathrm{i}$ lejren driver en fjendtlig propaganda og via England og Paris modtager aviser og nyheder. « $^{22}$

Den 9. marts 1916 refererede 'Provinzialverein vom Roten Kreuz für Schleswig-Holstein' folgende fra det franske blad 'Le Soleil du Midi' d. 9. januar 1916: 30 tyske fanger af dansk oprindelse (slesvigere) fra forskellige regioner blev i går kl. 7 om aftenen bragt til lejren Aurillac. Her nyder de den samme fortrinsbehandling som vore 'Elsass-Lothringer'. Generalkommandoen foranledigede på dette grundlag en overvågning af familierne og stemplede hele 
sagen hemmelig. ${ }^{23}$ Det var betydelige og alvorlige anklager, som blev rettet mod de omtalte dansksindede.

Det ovennæunte skal ikke give indtryk af, at de dansksindede friviligt gik i fransk fangenskab. Men når de blev taget til fange, bekendte en del af dem sig til de rød hvide farver og nød en bedre behandling. Om der er tale om almindelig pragmatisme eller national bevidsthed må stå åbent.

\section{Desertationer}

En anden sag $i$ denne sammenhæng er Flensborg-politiets før nævnte generalisering: "Desertationer var ikke politiet bekendt.« ${ }^{24}$

Allerede i begyndelsen af 1915 sendte den kommanderende general for det IX. armekorps, v. Falk, en hemmelig meddelelse til overpræsidenten i Slesvig. Her bad generalen om, at man tillagde den danske bevægelse den skarpeste opmarksomhed. Det hang tæt sammen med, at man havde registreret en række desertationer. ${ }^{25}$

Den 25.11.1917 fik Flensborgs 'Kriegswirtschaftsstelle' følgende meddelelse: "I den sidste tid er flere soldater fra hæren ikke vendt tilbage fra deres orlov til Nordslesvig. Ifølge efterforskningerne er de omtalte deserteret og sandsynligvis taget over grænsen til Danmark « ... Krigsministeriet anbefaler: "... at man lægger mere vægt på ansøgernes og deres familiers politiske holdning og om nødvendigt overvåger ansøgerne og familiemedlemmer endnu mere end hidtil, for derved at undgå fremtidige deserteringer. « $^{26}$

Regeringspræesidenten i Slesvig sendte sine rapporter til kejser og konge Wilhelm d. II. Den 27.4.1918 måtte han underdanigt bl.a. meddele, at den danske befolkning ikke tegnede mange krigslån, og han tilføjede: „Faneflugt og unddragelsen af militærpligten varer i uformindsket styrke ved i Nordslesvig." Videre står der: "Flygtningene får frataget deres prøjsiske statsborgerskab. Tilfredshed herover i den loyale del af befolkningen. « $^{27}$ Den tyske administration var med andre ord meget opmærksom på deserteringerne.

En tidlig vurdering af faneflugtens omfang finder man hos $\mathrm{M}$. Lauesen der mente, at kun lidt over $1 \%$ af de 30.000 indkaldte, dvs. 300, deserterede. Svend Falkner Sørensen argumenterede (1989) overbevisende for at tallet var mindst $2423{ }^{28}$ Tager man udgangspunkt i de tidligere omtalte $25.500-30.000$ krigsdeltagere, så deserterede mellem $8 \%$ og $11 \%$ !

Ser man på en grafisk afbildning af flugttidspunktet (figur 2), fremkommer tre markante stigninger. S. F. Sørensen tolker figuren og dermed forholdene, og han konkluderer: "Alt $i$ alt må man sige, at de store slag ikke $i$ sig selv har affødt omfattende deserteringer, selv om de ganske givet har spillet en underordnet rolle. $\ll^{29}$ Denne konklusion kan imidlertid nuanceres, og der viser 
sig da en påfaldende sammenhæng mellem tabsbølgerne og deserteringerne til Danmark.

Figur 2.

\section{Flugttidspunkt.}

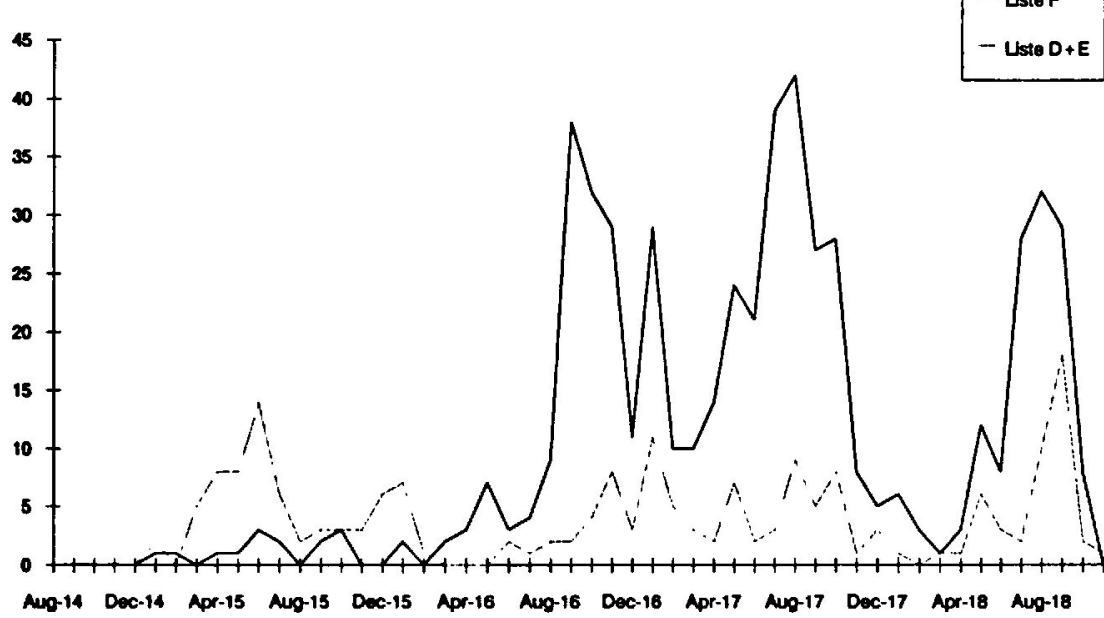

Gengivet efter Svend Falkner Sørensen: Faneflugt? Dansksindede soldaters flugt fra tysk krigstjeneste 1914-18 (1989)

Figur $3^{30}$ :

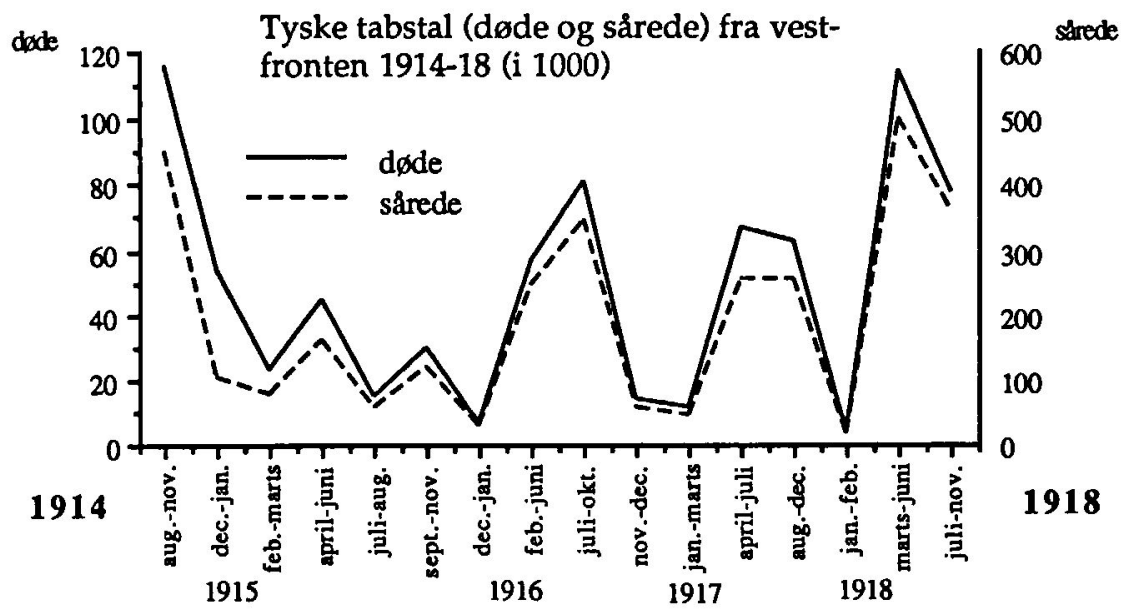


Tager man udgangspunkt i det statistiske materiale over døde og sårede fra kampene ved vest-fronten, så kan følgende figur tegnes (figur 3):

Ligesom figur 2 har denne figur tydelige markeringer. Der er 4 perioder, hvor tabstallene stiger markant. Det samme fremgår af figur $4 \mathrm{i}$ bilaget. Den første stigning er udtryk for 'Schlieffenplan'-offensiven, som blev udkæmpet med store mennesketab.

Den følgende markerer de hårde kampe ved 'Verdun' (februar-juli) og 'Somme' (juni-november) i 1916. Disse to slag gik nærmest over $\mathrm{i}$ hinanden og betød et stort pres for soldaterne. I en dagbog fra Flensborg, kan man den 22. januar 1917 læse om to kompagnier, der kom hjem direkte fra 'Somme': "De så slemme ud ... Julius har talt med en af dem, vedkommende har været ved fronten i 30 måneder uden orlov. « ${ }^{31}$

Den næste stigning hænger sammen med de voldsomme kampe i forbindelse med de allieredes store offensiver fra marts og april 1917. Champagnes, Arras' og Flanderns jord blev farvet rød af de faldnes blod. Disse voldsomme, men i sidste ende resultatløse kampe var bl.a. årsag til store soldatermytterier $\mathrm{i}$ den franske hær. Mellem 500 og 1.500 soldater blev henrettet.

Den sidste bølge markerer den tyske hærledelses afsluttende og mislykkede forsøg på at bryde gennem de allieredes linier og fremtvinge sejren i foråret 1918. Kommandanten for regiment "Königin« skrev i december 1916 til Flensborgs borgmester, at man havde vundet hæderfulde sejre. Selv om der var svære tab, så var de beskedne i forhold til succesen. Nu i marts 1918 var situationen en anden: "Tabstallene var temmelig høje, regimentet tabte 42 officerer, 4 fanejunkere og 1076 menige. $\kappa^{32}$ Skyttegravskrigen var et helvede!

Jeg mener ikke, at figurernes lighed er tilfældig, de er derimod udtryk for desertørens umiddelbare bevæggrund. Han var sluppet fra helvedet og ville ikke tilbage. De danske soldater var hovedsagelig koncentreret $\mathrm{i}$ 'Füsilierregiment 86' og 'Reserve-Füsilierregiment 86'. Derudover bl.a. i 'Infanteriregiment 84' og 'Reserve-Infanterieregiment $85^{\prime} \cdot{ }^{33}$ De ovennævnte deltog $i$ høj grad i kampene ved vest-fronten. Flensborg Avis ${ }^{34}$ bragte den 23.11.1916 en omtale af en retssag mod en ung mand, der havde forsøgt at komme over grænsen. Hans forklaring på faneflugten var enkel; han var bange for at komme i krig. ${ }^{35}$

En lignende reaktion kommer frem i en af de mest gribende scener hos $\mathrm{E}$. M. Remarque. Det er beskrivelsen af hovedpersonen Paul's orlov. Da han går op ad trapperne, møder han sin søster, der råber hans navn og farer ind til hans syge mor. Efter den hårde tid ved fronten, er Paul nu ved at bryde sammen: "Jeg kan ikke gaa videre. Moder, Moder, det er Paul.

Jeg læner mig til Væggen og klamrer om min Hjælm og mit Gevær. Jeg klamrer om dem, saa fast jeg kan; men jeg kan ikke gaa et skridt længere, Trappen svømmer bort for mine Øjne, jeg kommer til at støde Kolben imod 
Fødderne og presser forbitret Tænderne sammen; men jeg kan ikke bære det, jeg anstrenger mig pinagtigt for at tale eller le; men jeg faar ikke et Ord over mine Læber, og saa staar jeg paa Trappen, ulykkelig, hjælpeløs, i en frygtelig Krampe, og vil ikke, og Taarerne løber mig stadig saadan ned over ansigtet. $\aleph^{36}$

\section{Afslutning}

I det foregående er to emner blevet behandlet nærmere; fangenskab og faneflugt. Begge emner er blevet set med henblik på spørgsmålet om danskhedens 'tunge byrde' som soldater i verdenskrigen.

Fra et tysk nationalt synspunkt var de dansksindedes opførsel i fransk fangenskab ensbetydende med landsforræderi og medførte den preussiske statsmagts opmærksomhed. Et spændende, men ubesvaret spørgsmål i denne forbindelse er de dansksindedes holdning i fangelejren. Var deres opførsel patriotisk eller pragmatisk betinget?

I den tyske hær kæmpede bl.a. polsk-, fransk- og dansksindede soldater side om side med de tyske soldater. ${ }^{37}$

Den preussiske administration var klar over deserteringerne, og man anså dem for at være et alvorligt problem. Ved hjælp af bl.a. en skærpet overvågning og fratagelsen af statsborgerskabet m.m. prøvede man at virke straffende og forebyggende. Men de høje tal for desertører anskueliggør, at forholdsreglerne ikke var særlig effektive.

Sammenligningen mellem tidspunkterne for faneflugt og de høje tabstal fra vest-fronten har vist en tydelig sammenhæng. Skyttegravens ragnarok udgjorde for soldaterne en umenneskelig belastning. Disse oplevelser bevirkede, at de dansk-sindede soldater i orloven kunne 'lette' deres 'tunge byrde' ved at flygte over grænsen.

\section{LITTERATUR:}

Feldman, G. D.: "Armee, Industrie und Arbeiterschaft in Deutschland 1914 bis 1918«. Bonn 1985. Gutsche, Willibald m.fl.: »Der Erste Weltkrieg Ursachen und Verlauf«. Köln 1985.

Hansen, Hans Schultz: "Danskheden i Sydslesvig 1840-1918 - som folkelig og national bevægelse «. Flensborg 1990.

Jünger, Ernst: »In Stahlgewittern«. Stuttgart 1961.

Jürgensen, W.: "Füsilier-Regiment Königin nr. 86«. 1925.

Kühl, Jørgen, Jens Ødegaard: "Dansksindede sønderjyske krigsdeltagere og faldne i Første Verdenskrig« i Sønderjyske Årbøger 1990 s. 167-174.

la Cour, Vilhelm: "Sønderjylland under Verdenskrigen August 1914-16«. København 1916.

Lammers K. C., m.f.: „Krigsbilleder og Krigsoplevelser: Soldaternes ferste verdenskrig« i Den Jyske Historiker Bd. 31-32 s. 75-120.

Lauesen, Marcus: „Fortællinger af Grænselandets Historie« Bd. 2, 1939. 
Mai, Gunther: "Das Ende des Kaiserreichs« dtv 1987.

Meerwarth, R., Günther, A., Zimmermann W.: »Bevölkerungsbewegung, Einkommen und Lebensverhältnissew 1932.

Remarque, E. M.: »Intet nyt fra vestfronten« København 1929 (5. oplag).

Sørensen, Svend Falkner: "Faneflugt? Dansksindede soldaters flugt fra tysk krigstjeneste 1914-18 « Aabenraa 1989.

\section{ANVENDTE ARKIVER M.M.:}

\section{Stadtarchiv Flensburg (St.A)}

II C 127 bd. 1: Verschiedene Sachen betr. dem Krieg 1914-20

II C 129 Regiment Königin

VII B 1 bd. 2: Dänentum betr. Generalakten 1912-23

VIII B 306: UK Zurückstellung

HS 1010 - Heinrich Schröder: Chronik des Weltkrieges in täglichen Aufzeichnungen

Arkivet ved Dansk Centralbibliotek for Sydslevig (A.DCB)

Nr. 331: J. Ankersens arkiv

P 295: Niels Kjems' arkiv

Geheimes Staatsarchiv Preussischer Kulturbesitz Abteilung Merseburg (GStA Merseburg)

Rep. 89 H. Bestand 2.2.1 nr. 16592: Die Zeitungsberichte des Regierungs-präsidenten zu Schleswig. Rep. $120 \mathrm{CB} 1 \mathrm{Nr} .147 \mathrm{Bd}$. 3: Die dänische Protestbewegung in Nordschleswig (: dänische Pressestimmen) 1914-15.

\section{Derudover er anvendt:}

Flensborg Avis

Statistisches Jahrbuch für das Deutsche Reich (St.J.f.d.D.R.)

"Ursachen und Folgen - Vom deutschen Zusammenbruch 1918 und 1945 bis zur staatlichen Neuordnung Deutschlands in der Gegenwart«. Bd. 1 Berlin 1958 (Ursachen und Folgen).

\section{Bilag.}

\section{Figur 4}

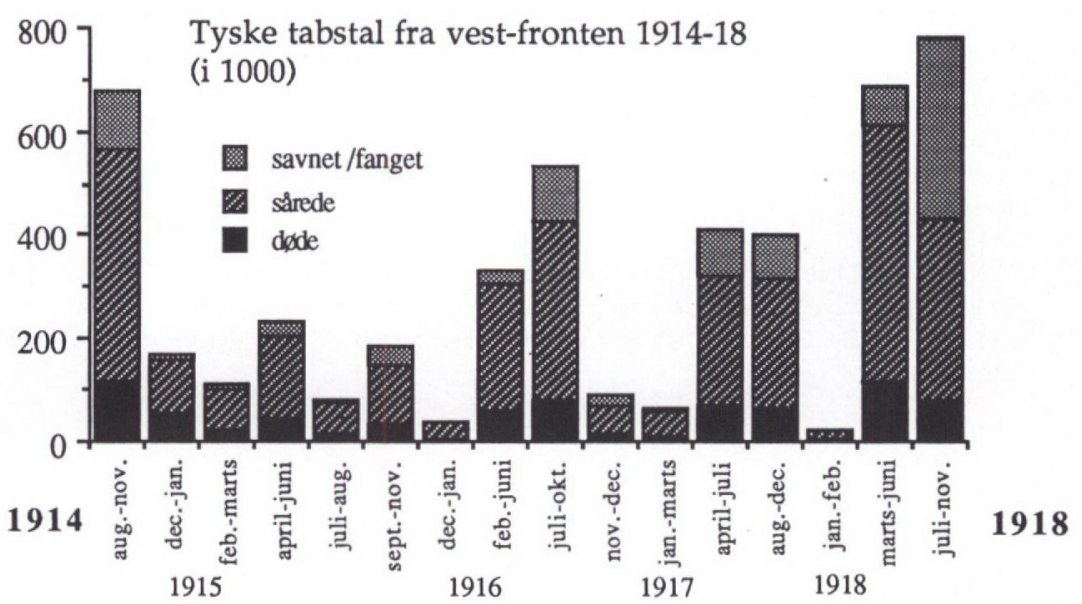

Kilde: Statistisches Jahrbuch für das Deutsche Reich bd. 42 s. 29 


\section{NOTER}

Anm.: Tysksprogede citater er generelt oversat til dansk.

1. Feldman s. 424ff.

2. Se f.eks. Lammers s. 75-120.

3. St.f.d.D.R. bd. 42 s. $28 f$.

4. Remarque s. 263 , se desforuden bl.a. Gutsche s. $170,247 \mathrm{f}$.

5. Meerwarth s. $71 f$.

6. Feldman s. 38.

7 Ursachen und Folgen bd. 1 s. 180 f.

8 St.A. II C 127 bd. 1.

9 A. DCB nr. 331 s. 2 . Her oversat.

10. Mai s. 68.

11. A. DCB nr. 331 s. 6. Her oversat.

12. W. Jürgensen s. 233.

13. J. Kühl s. 173.

14. la Cour s. 75.

15. Lauesen s. 226.

16. H. S. Hansen s. 348.

17. Lammers s. 93 f.

18. Remarque s. $78 \mathrm{f}$.

19. Lauesen s. 228. Et almindeligt svar $\mathrm{i}$ forbindelse med risikoen ved flugten ${ }^{\prime} .$. hellere dø end tilbage til Skyttegraven."

20. GStA Merseburg Rep. 120 CB I Nr. 147 Bd.3.

21. St.A. VII B I bd. 2.

22. St.A. VII B I bd. 2.

23. St.A. VII B I bd. 2.

24. H. S. Hansen s. 348.

25. St.A. VII B 1 bd. 2.

26. St.A. VIII B 306.

27. GStA Merseburg Rep. 89 H Bestand 2.2.1. nr. 16592.

28. Sørensen s. 25 på basis af Karl Alnor: Handbuch zur schleswigschen Frage. bd. II 1928, s. 854.

29. Sørensen s. 60 .

30. St.J.f.d.D.R. bd. 42 s. 29.

31. St.A. HS 1010 s. 180 . Her oversat.

32. St.A. II C 129.

33. la Cour s. 70 .

34. Fl. Avis blev forbudt fra d. 11.-28.8.1914 og fra d. 2.-10.11.1915.

35. Flensborg Avis d. 23.11.1916.

36. Remarque s. 153.

37. A. DCB P 295-2 I et brev til den senere vandrelærer Niels Kjems fra vennen V. Nielsen d. 24.3.15: "Vi har nu faat nye Soldater i Kvater ... Med dem er der kommen nogle paa 16, 17 og 18 Aar gamle Karle nede fra Elsass. De er kommen herop for, at de ikke flygter over Gransen til Frankrig .... 